UDC 539.3

\title{
EVALUTION ON STRESS DISTRIBUTION, DEFORMATION RATE IN EMBANKMENT AND SOFT SOIL REINFORCED CONCRETE PILE COMBINED GEOTEXTILE BELOW THE EMBANKMENTS IN GEOLOGICAL CONDITIONS MEKONG DELTA
}

\author{
Nguyen Anh Tuan ${ }^{1}$, \\ $\mathrm{PhD}$ \\ Nguyen Tuan Phuong ${ }^{2}$, \\ $\mathrm{PhD}$ \\ ${ }^{1}$ Hochiminh City University of Transport, \\ No. 2, D3 St., Ward 25, Binh Thanh Dist., Hochiminh City, Vietnam \\ ${ }^{2}$ Hochiminh City University of Technology, \\ No. 268, Ly Thuong Kiet St., Dist. 10, Hochiminh City, Vietnam
}

The main content of the paper is evalution stress distribution, deformation rate in embankment and soft soil reinforced concrete pile combined geotextile below the embankments in geological conditions in Mekong delta by finite element method to Geotechnique-designer have to notice the correlation of rational pile-distance and embankment-depth when design weak foundation.

Keywords: Geosynthetic reinforced pile, soft soil, pile embankment, foundation, FEM.

\section{Introduction}

With the rapid growth of the economy and the trend of industrialization and mordenization of the country, the demand of developing buildings, factories and other infrastructures in Vietnam increases, especially in the Mekong Delta area. Because of the geological structure property of Mekong Delta is mainly soft soil, the foundation depth can vary from 30 to $40 \mathrm{~m}$. To meet the demand of infrastructure development, there some studies and researches done recently on this geological structure.

The divergent subsidence due to causeway, path way to the bridge, storage has caused difficulty for the transportation and facility in some areas in Hochiminh city. For instance, according to Hochiminh city Transportation Department, the sunsidence on Nguyen Huu Canh street varies from 0.5 to $1 \mathrm{~m}$. There are some proposal solutions to solve this issue such as concrete piles, sand piles, reinforced concrete, soil\&cement mixture to reduce load, etc... These solutions takes a lot of time and are not efficient. Recent years, there is a solution for the foundation called "The embankment on the pile conbined with geotextile". Hopefully this solution will solve the issue.

The evaluation and analysis on stress distribution, ground deformation and reinforced concrete and geotextile treatment on soft soil is extremely essential to find the new solution to improve the quality of foundation in Mekong Delta area.

\section{Theoretical basis}

\subsection{Theory of soil arching}

According Terzaghi (1943) arching effects have been described. Arching effects base on his experiment on the trap-door effects as shown in Fig. 1.

(C) Nguyen Anh Tuan, Nguyen Tuan Phuong 
Stress Distribution Equation:

$$
\left(\sigma_{z}+\mathrm{d} \sigma_{z}\right)^{*} S-\sigma_{z}^{*} S+2 \tau_{x z} \mathrm{~d} z-\mathrm{d} G=0 .
$$

With $\sigma_{z}$ is vertical effective Stress ( $Z$ direction), $\tau_{x z}$ is shear stress on $x z$ plane, $S$ is width of trap-door, $G$ is weight of soil on trap-door, $\gamma$ is the soil unit

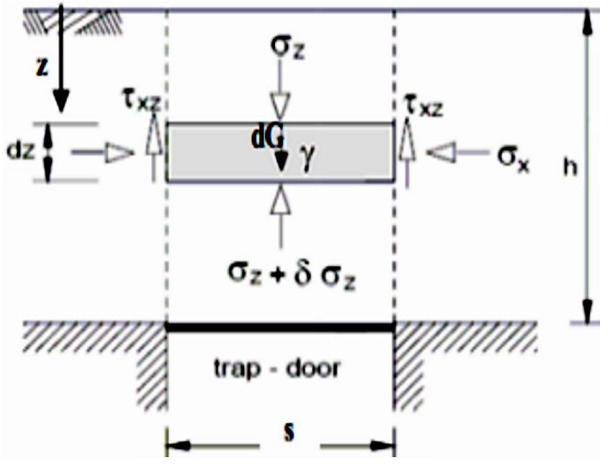

Fig. 1. Description of soil Arching analysis with Terzaghi's method weight.

The equivalent equation:

$$
\mathrm{d} \sigma_{z}^{*} S=\gamma^{*} S \mathrm{~d} z-2 \tau_{x z} \mathrm{~d} z \text {. }
$$

According to MohrCoulomb, the Shear Stress at failure can be expressed as:

$$
\tau_{x z}=C^{\prime}+\sigma_{x} \tan \varphi^{\prime} .
$$

With $C^{\prime}$ and $\varphi^{\prime}$ are the effective cohesion and friction angle of the soil. The effective horiziontal stress as afunction of verticle effective stress is $\sigma_{x}=\sigma_{z}^{*} K$, Terzaghi determined

that $K=1$ based on his experimental results.

The equation is written as:

$$
\mathrm{d} \sigma_{z}^{*} S=\gamma^{*} S \mathrm{~d} z-2\left(C^{\prime}+\sigma_{z} K \tan \varphi^{\prime}\right) \mathrm{d} z .
$$

Dividing both side of Equation (4) with $\sigma_{z}$ and $s$ :

$$
\left(\frac{\mathrm{d} \sigma_{z}}{\sigma_{z}}\right)=\frac{\gamma}{\sigma_{z}} \mathrm{~d} z-\frac{2 C}{s^{*} \sigma_{z}} \mathrm{~d} z-\frac{2 K^{*} \tan \varphi}{s} \mathrm{~d} z .
$$

The solution for the differential equation is as follows

$$
\sigma_{z}=\frac{S^{*}\left(\gamma-2 C^{\prime} / S\right)}{2^{*} K^{*} \tan \varphi^{\prime}}\left\{1-e^{-2 K \tan \varphi^{\prime} \frac{z}{S}}\right\}+p^{*} e^{-2 K \tan \varphi^{\prime} \frac{z}{s}} .
$$

According to the result found by Terzaghi, $K=1$. Solve equation (6) gives an exponentially increasing vertical effective stress within the embankment fill between the two rigid foundations. Comparison between effective vertical stress distribution with the linearly increasing geostatic vertical stress is shown in Fig 2. Due to arching, the vertical stress acting on the ground surface below the embankment is much lower than the geostatic vertical stress.

Arching is difined by Mc. Nulty (1965) as "The ability of a material to transfer from one location to another in response to a relative displacement between the location. A system of shear stresses is the mechanism by which the loads are transfer". 
The Nordic Guiline method helps analyze arching in soil is suggested by Carlsson (1987), this method shows the angle of arching is 30 degrees refer to Fig. 5.

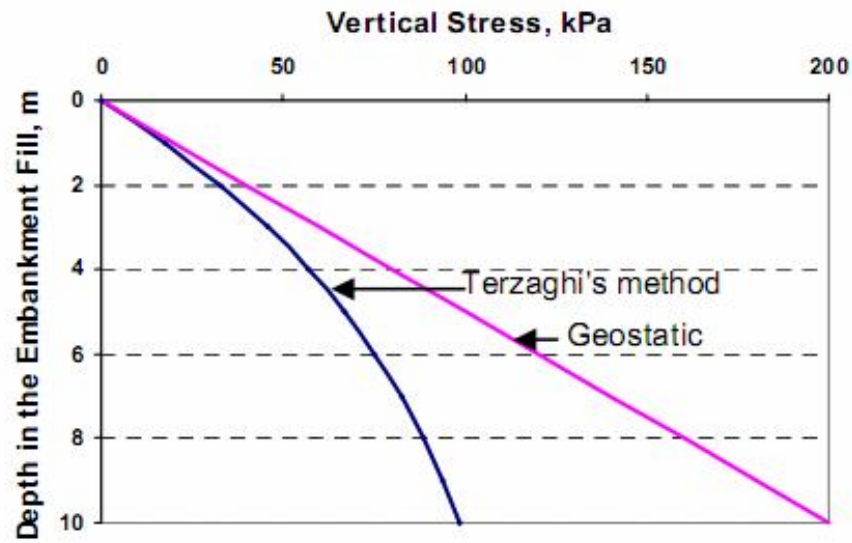

Fig. 2. Typical vertical stress distribution of embankment fill between trap-door of Terzaghi

Weight of the soil is calculated in $2 \mathrm{D}$ as below:

$$
W=\frac{(b-a)^{2}}{4 \tan 15^{\circ}} \gamma,
$$

with $a$ is the width of the pile, $b$ is the distance between the centre of 2 piles, $\gamma$ is unit weight of the embankment.

Svant et al. (2000) suggested the soil weight formula in 3D

$$
W=\frac{\gamma}{2 a}\left\{b^{2} H-\frac{1}{6 \tan \beta}\left[(a+H \tan \beta)^{3}-a^{3}\right]\right\} .
$$

With $a$ is the width of the pile, $b$ is the distance between the centre of 2 piles, $\gamma$ is the soil unit weight, $H$ is the height of soil layer.

Development by Jones et al. (1990) based on the past study by Marston and Anderson (1913) about the peak of the spherical dome between piles.

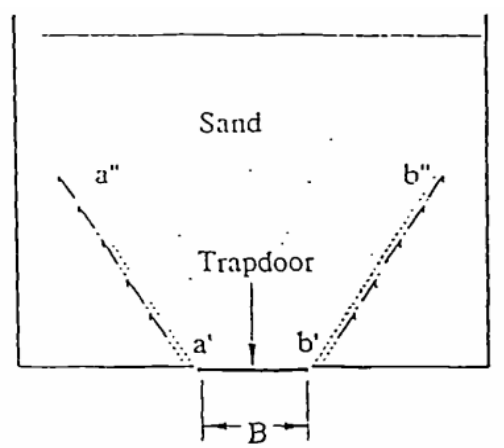

Fig. 3. The shear stress path when trap-door min displacement of Terzaghi

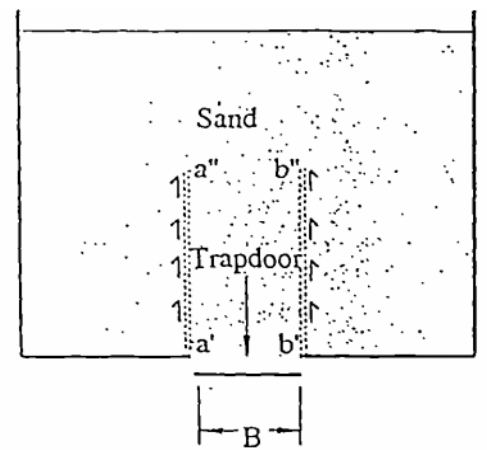

Fig. 4. The shear stress path when trap - door max displacement of Terzaghi 


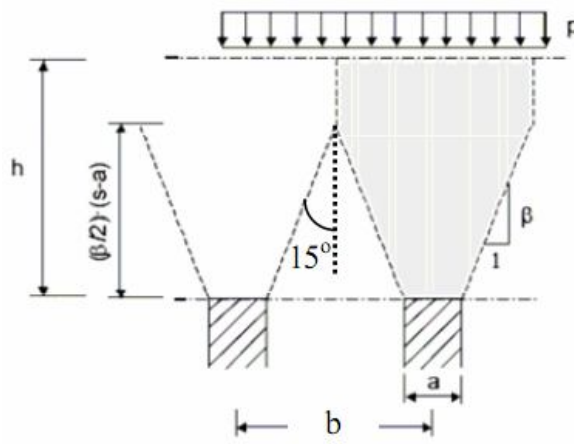

(a)

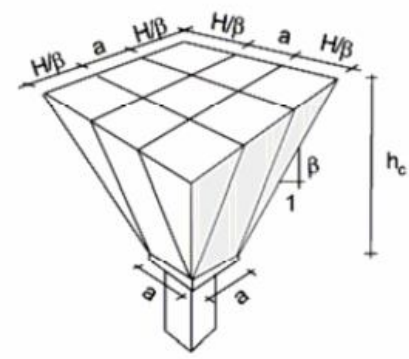

(b)

Fig. 5. Soil wedge model (a) 2D; (b) 3D defined by Carlsson

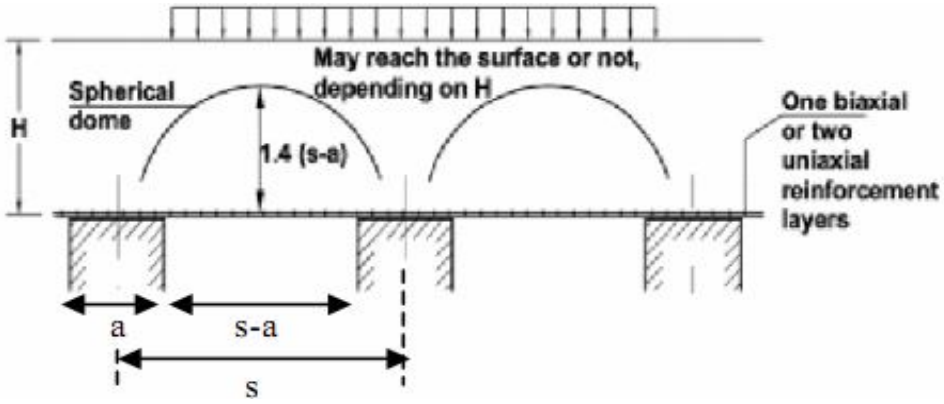

Fig. 6. Hemispheric in BS 8006

Analyze the spherical dome based on the ratio between pressure on the pile and vertical stress on the soft soil layer, $P_{c}^{\prime} / \sigma_{v}$

$$
P_{c}^{\prime}=\delta_{v}^{\prime}\left[\frac{C_{c} a}{H}\right]^{2} \text {. }
$$

With: $C_{c}$ is soil arching coefficient $\left(C_{c}=1.95(\mathrm{H} / \mathrm{a})-0.18\right.$ for end-bearing pile, $C_{c}=1.5(\mathrm{H} / \mathrm{a})-0.07$ for friction and other pile), $a$ is the size of the pile caps, $H$ is the height of the embankment.

\subsection{Load Transfer}

McNulty (1965) and Kempton (1998) The ratio of the vertical stress on top of the cap:

$$
\rho=\frac{P_{b}}{\gamma H+q_{0}} .
$$

Where: $p_{p}$ is average vertical pressure above geosynthetic, $q_{0}$ is uniform surcharge on the embankment, $T$ is tension on geotextile, $\rho=0$ : Represents the Complete soil arching / $\rho=1$ : Represents no soil arching, $\gamma$ is the soil unit weight. 


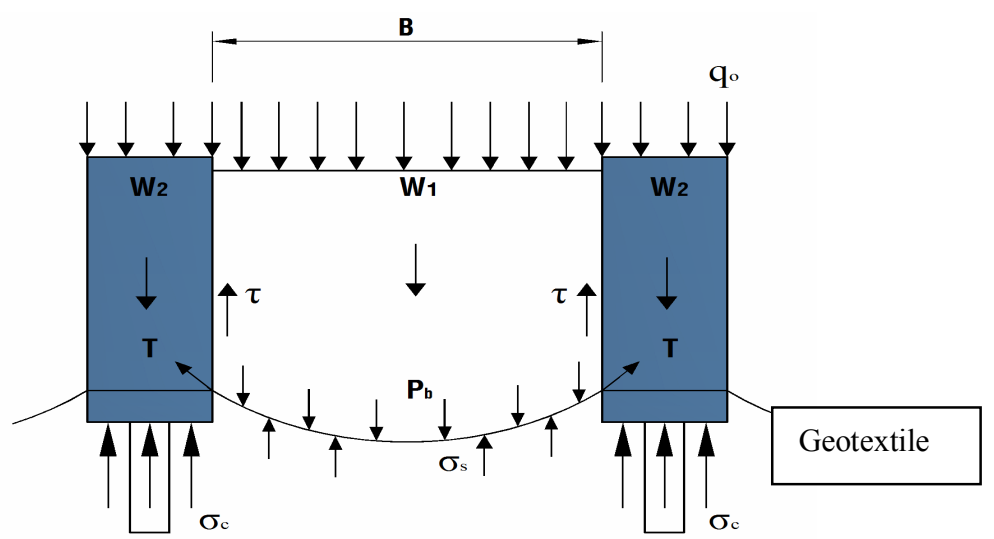

Fig. 7. Load transfer (cited in Li, 2002)

Han (2003) The ratio of the vertical stress on top of the cap:

$$
n=\frac{\sigma_{c}}{\sigma_{s}} .
$$

With $\sigma_{c}$ is vertical stress on pile, $\sigma_{s}$ is vertical stress between piles.

Schimidt (2004) The ratio of the vertical stress on top of the cap:

$$
\mathrm{LKF}=\frac{Q}{Q_{s}}=\frac{\sigma_{c}^{*} A_{c}}{\gamma^{*} H^{*} A_{c}}
$$

$\Gamma$ is the soil unit weight, $H$ is height of embankment, $A_{c}$ is Cross sectional area of pile.

\subsection{Factor that determines arching}

Ratio that determines arching

CSR is the column stress ratio

SRR is the stress reduction ratio

$N$ is the ratio of the vertical stress on top of the cap and $E$ The piled embankment efficacy.

$$
\begin{gathered}
\mathrm{CSR}=\frac{\sigma_{c}}{\sigma}=\frac{\sigma_{c}}{(\gamma H+q)}, \\
\mathrm{SRR}=\frac{\sigma_{s}}{\sigma}=\frac{\sigma_{s}}{(\gamma H+q)}, \\
n=\frac{\sigma_{c}}{\sigma_{s}}, \\
E=\frac{\sigma_{c} x a_{s}}{\sigma} .
\end{gathered}
$$

With: $\gamma$ is the soil unit weight, $H$ is height of soil layer, $q$ is surcharge load,

$$
a_{s}=\frac{A_{c}}{A_{c}+A_{s}},
$$

$A_{c}$ is pile cross sectional area, $A_{s}$ is area of the soil associated with the column. 


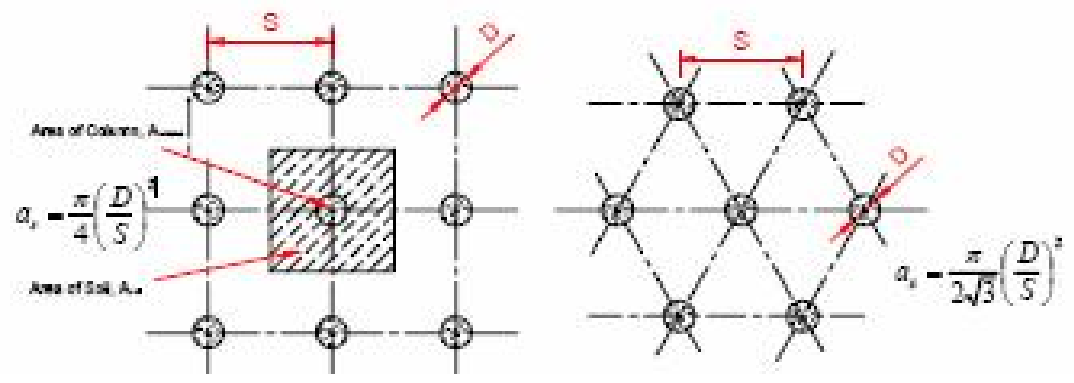

Fig. 8. Area replacement ratio

According to BS8006:1995 and some researchers, SRR is calculated as Table 1.

Table 1

The stress reduction ratio

\begin{tabular}{|c|c|c|c|}
\hline No. & & The stress reduction ratio & No. Equa \\
\hline 1 & $\begin{array}{l}\text { BS } 8006 \\
1995\end{array}$ & $\begin{array}{l}S R R=\frac{2 * S^{*}(\gamma H+q)(S-a)}{\left(S^{2}-a^{2}\right)^{2} * \gamma H} *\left[S^{2}-a^{2}\left(\frac{P_{c}^{\prime}}{\gamma H}\right)\right] \\
\text { With } \mathrm{H} \leq 1.4(\mathrm{~S}-\mathrm{a}) \\
S R R=\frac{2.8^{*} S}{(S+a)^{2} * H} *\left[S^{2}-a^{2}\left(\frac{P_{c}^{\prime}}{\gamma H}\right)\right] \\
\text { With } \mathrm{H}>1.4(\mathrm{~S}-\mathrm{a}) \\
\text { With } \frac{P_{c}^{\prime}}{\gamma H}=\left(\frac{C_{c} a}{H}\right)^{2}\end{array}$ & $\begin{array}{l}(17) \\
(18) \\
(19)\end{array}$ \\
\hline 2 & Terzaghi & $S R R=\frac{\left(S^{2}-a^{2}\right)}{4 * H^{*} a^{*} K^{*} \tan \phi}\left\{1-e^{\frac{-4 H a K \tan \phi}{s^{2}-a^{2}}}\right\}$ & (20) \\
\hline 3 & $\begin{array}{l}\text { Randolph } \\
1988\end{array}$ & $S R R=\frac{1}{\left[\frac{2 K_{p}}{K_{p}+1}\right]\left[\left(1-\frac{a}{s}\right)^{\left(1-K_{p}\right)}-\left(1-\frac{a}{s}\right)\left(1+\frac{a}{s} K_{p}\right)\right]+\left(1-\frac{a^{2}}{s^{2}}\right)}$ & (21) \\
\hline 4 & Guido & $S R R=\frac{(s-a)}{3 \sqrt{2} \cdot H}$ & (22) \\
\hline 5 & Low 1994 & $S R R=\frac{\left(K_{p}-1\right)(1-\delta) S}{2 H^{*}\left(K_{p}-2\right)}+(1-\delta)^{\left(K_{p}-1\right)}\left[1-\frac{S}{2 H}-\frac{S}{2 H\left(K_{p}-2\right)}\right]$ & (23) \\
\hline 6 & Carlsson & $S R R=\frac{\mathrm{s}-\mathrm{a}}{4 \cdot H \cdot \tan 15^{0}}$ & (24) \\
\hline 7 & $\begin{array}{l}\text { Kivilo } \\
1998\end{array}$ & $\begin{array}{l}C S R=\frac{1}{a_{s}+\frac{E_{\text {soil }}}{E_{\text {col }}}\left(1-a_{s}\right)} \\
S R R=\frac{E_{\text {soil }}}{E_{\text {col }} a_{s}+E_{\text {soil }}\left(1-a_{s}\right)}\end{array}$ & (25) \\
\hline
\end{tabular}


In which: $H$ is height of the embankment, $q$ is external load, $s$ is distance between pile center, $a$ is Area replacement ratio, $C_{c}$ is arching coefficient $\left(C_{c}=1.95(\mathrm{H} / \mathrm{a})-0.18\right.$ for end-bearing pile, $C_{c}=1.5(\mathrm{H} / \mathrm{a})-0.07$ for friction and other pile), $p^{\prime}$ is angle of friction of the embankment fill, $K$ is coefficient of later earth pressure $(K=1)$

$$
K=\frac{1+\sin \varphi}{1-\sin \varphi}
$$

is Rankine coefficient of passive earth pressure, $E_{c o l}$ is Modulus of elasticity of the column, $E_{\text {soil }}$ is Modulus of elasticity of the unstabilized soil surrounding the column.

\section{The embankment on the pile conbined with geotextile}

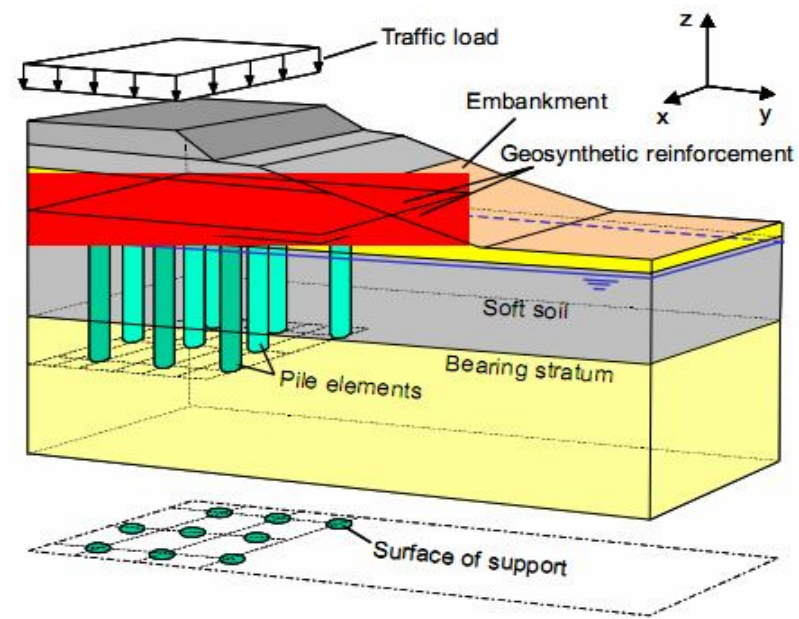

Fig. 9. Geosynthetic reinforced pile supported embankment [4],[5]

Arching in embankment.

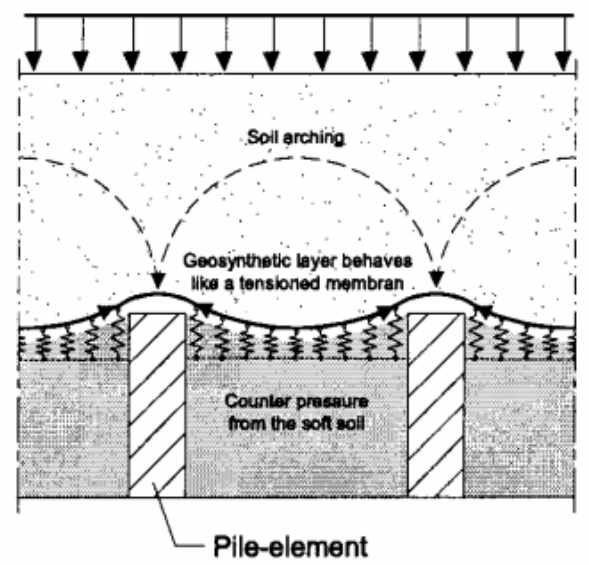

Fig. 10. Arching in embankment [4], [5] 


\subsection{Geosynthetic reinforcement}

\subsubsection{BS 8006 (1995)}

One of the formulas to calculate the tension force in the geosynthetic based on the BS 8006 is as follows.

$$
T_{r p}=\frac{W_{T}(s-a)}{2 a} \sqrt{1+\frac{1}{6 \varepsilon}},
$$

where $T_{r p}$ is the tensile force per meter geosynthetics, $W_{T}$ is distributed vertical load acting on the geosynthetic between the piles, $\varepsilon$ is the strain in the geosynthetics (\%), $a$ is the pile cap size and $\mathrm{s}$ is the center-to-center spacing.

\subsubsection{Zaeske (2001) and Kempfer (2002)}
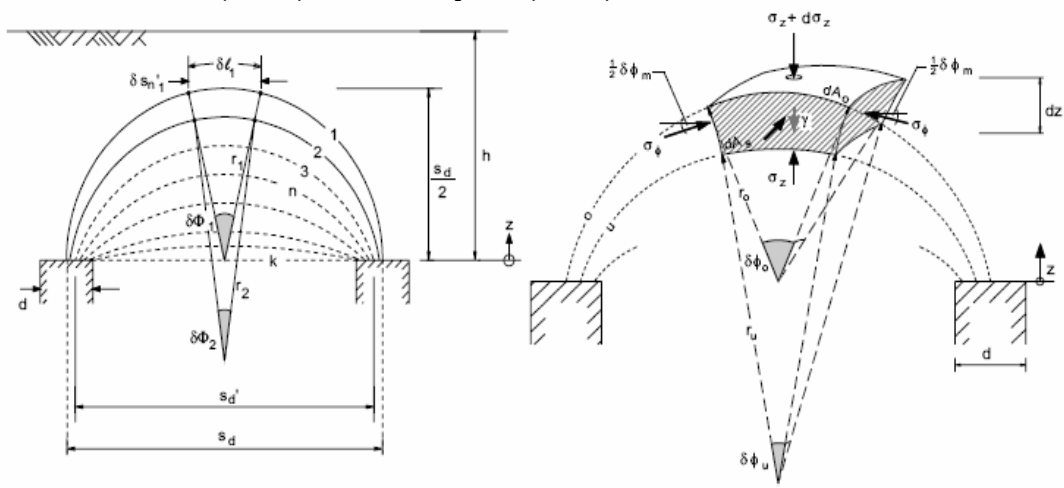

Fig 11. Multi aching model [2]

The equation is developed:

$$
-\sigma_{z} \mathrm{~d} A_{u}+\left(\sigma_{z}+\mathrm{d} \sigma_{z}\right) \mathrm{d} A_{0}-4 \sigma_{\varphi} \mathrm{d} A_{S} \sin \left(\frac{\delta_{\varphi_{m}}}{2}\right)+\gamma \mathrm{d} V=0 .
$$

Where:

$$
\begin{gathered}
\mathrm{d} A_{u}=\left(r \delta_{\varphi}\right)^{2}, \\
\mathrm{~d} A_{0}=(r+\mathrm{d} r)^{2} \cdot\left(\delta_{\varphi}+\mathrm{d} \delta_{\varphi}\right)^{2}=2 \mathrm{~d} \delta_{\varphi} \cdot r^{2} \cdot \delta_{\varphi}+2 \mathrm{~d} r \cdot r \cdot \delta_{\varphi}{ }^{2}+r^{2} \cdot \delta_{\varphi}{ }^{2}, \\
\mathrm{~d} A_{S}=\left(r+\frac{1}{2} \mathrm{~d} r\right) \cdot\left(\delta_{\varphi}+\frac{1}{2} \mathrm{~d} \delta_{\varphi}\right) \cdot \mathrm{d} z=\mathrm{d} z \cdot r \cdot \delta_{\varphi}, \\
\mathrm{d} V=\left(r+\frac{1}{2} \mathrm{~d} r\right)^{2} \cdot\left(\delta_{\varphi}+\frac{1}{2} \mathrm{~d} \delta_{\varphi}\right)^{2} \cdot \mathrm{d} z=\mathrm{d} z \cdot r^{2} \cdot \mathrm{d} \delta_{\varphi}{ }^{2} .
\end{gathered}
$$

The equation is developed the tension force in the geosynthetic:

$$
\begin{gathered}
\frac{\mathrm{d}^{2} z}{\mathrm{~d} x^{2}}=\frac{q_{2}}{H}+\frac{C-x}{H}, \\
H=\frac{2 \cdot \int_{0}^{i} \sqrt{1+\left(z_{w}^{1}\right)^{2}} \cdot \mathrm{d} x+2 \cdot \int_{i}^{j} \sqrt{1+\left(z_{p}^{1}\right)^{2}} \cdot \mathrm{d} x-l_{0}}{2 \cdot \int_{0}^{i}\left(1+\left(z_{w}^{1}\right)^{2}\right) \cdot \mathrm{d} x+2 \cdot \int_{i}^{j}\left(1+\left(z_{p}^{1}\right)^{2}\right) \cdot \mathrm{d} x} .
\end{gathered}
$$


Where

$$
\begin{aligned}
& z_{W}(x)=A_{1, W} \cdot e^{\alpha_{W} \cdot x}+A_{2, W} \cdot e^{-\alpha_{W} \cdot x}-\frac{\beta_{W}}{\alpha_{W}^{2}}, \quad 0 \leq x \leq i, \\
& z_{W}^{\prime}(x)=\alpha_{W} \cdot\left(A_{1, W} \cdot e^{\alpha_{W} \cdot x}-A_{2, W} \cdot e^{-\alpha_{W} \cdot x}\right) .
\end{aligned}
$$

The tensile force per meter geosynthetic:

\subsection{Result of model}

$$
S(x)=\varepsilon(x) / J=H \cdot \sqrt{1+z^{\prime 2}(x)} .
$$
Measured values:
O $p=20 \mathrm{kN} / \mathrm{m}^{2}$
$\diamond p=54 \mathrm{kN} / \mathrm{m}^{2}$
$\Delta p=104 \mathrm{kN} / \mathrm{m}^{2}$
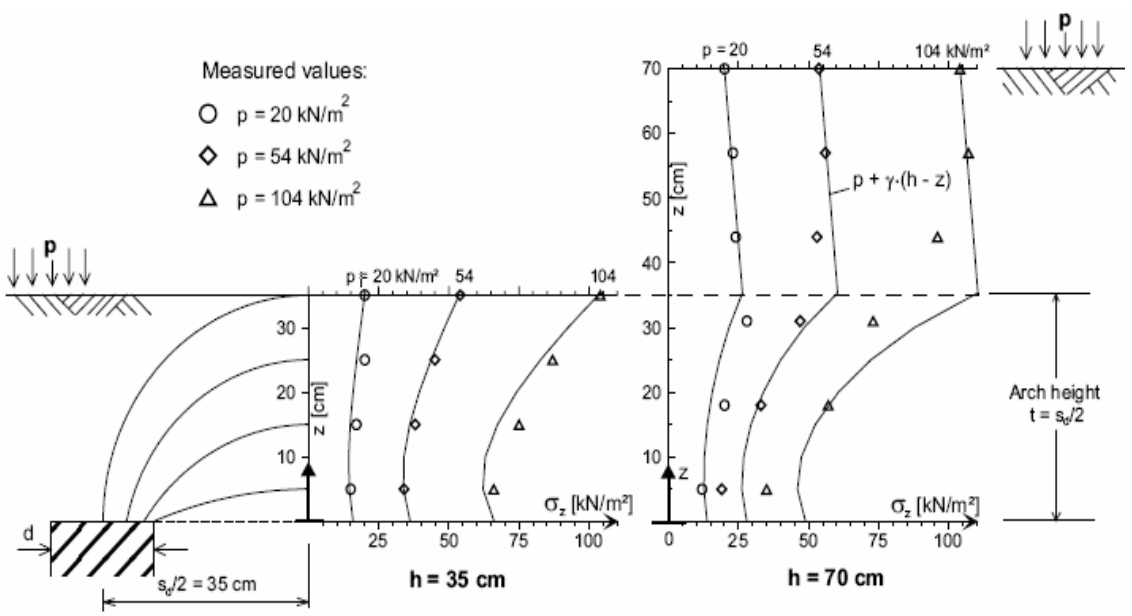

Fig. 12. The result of model Zaeske (2001) [2]

According to the experiment by Zaeske (2001), it is proven that the ratio of the arching in soil with the real dimension is $1 / 3$. This includes 4 piles in soft soil. On the top of each pile is covered by geotextile with the earth pressure cells.

The experiment result is recorded as below:

Case 1: distance between 2 piles $s=70 \mathrm{~cm}$, sand layer's thickness of $35 \mathrm{~cm}$, applied loads of $20 \mathrm{kN} / \mathrm{m}^{2}, 5420 \mathrm{kN} / \mathrm{m}^{2}, 10420 \mathrm{kN} / \mathrm{m}^{2}$. Vertical stress is measured at distance of $5 \mathrm{~cm}, 15 \mathrm{~cm}, 25 \mathrm{~cm}$ between and above the top of 2 piles.

Table 2

\section{Case 1}

\begin{tabular}{|c|c|c|}
\hline $\boldsymbol{p}(\mathrm{kPa})$ & $\boldsymbol{\sigma}\left(\mathrm{kN} / \mathrm{m}^{2}\right)$ & $\boldsymbol{h}(\mathrm{cm})$ \\
\hline 20 & $15-16-19$ & $5-15-25$ \\
\hline 54 & $33-42-45$ & $5-15-25$ \\
\hline 104 & $65-75-87$ & $5-15-25$ \\
\hline
\end{tabular}

Case 2: distance between 2 piles $s=70 \mathrm{~cm}$. sand layer's thickness of $70 \mathrm{~cm}$, applied loads of $20 \mathrm{kPa}, 54 \mathrm{kPa}, 104 \mathrm{kPa}$. Vertical stress is measured at distance of $5 \mathrm{~cm}, 20 \mathrm{~cm}, 30 \mathrm{~cm}, 45 \mathrm{~cm}, 55 \mathrm{~cm}$ between and above the top of 2 piles. 
Table 3

Case 2

\begin{tabular}{|c|c|c|}
\hline $\boldsymbol{p}(\mathrm{kPa})$ & $\boldsymbol{\sigma}\left(\mathrm{kN} / \mathrm{m}^{2}\right)$ & $\boldsymbol{h}(\mathrm{cm})$ \\
\hline 20 & $15-20-29-25-22$ & $5-20-30-45-55$ \\
\hline 54 & $20-33-46-54-57$ & $5-20-30-45-55$ \\
\hline 104 & $35-57-73-95-107$ & $5-20-30-45-55$ \\
\hline
\end{tabular}

\section{Design of ingenieurgesellschaft geotecgnik walz (igw) used for Hung} Loi metro in Can Tho City, Vietnam

The model uses cylindrical piles with diameter $D=300 \mathrm{~mm}$, spacing between piles $S=4000 \mathrm{~mm}$, reinforced concrete dimension of $1500 \times 1500 \times 300 \mathrm{~mm}$, above is geotextile with the height of $500 \mathrm{~mm}$ for big sand particles. Concrete layer 10x20 B.15 thickness of $250 \mathrm{~mm}$, rock layer 0x40mm thickness of $350 \mathrm{~mm}$.

The model is ilustrated in Fig.13.

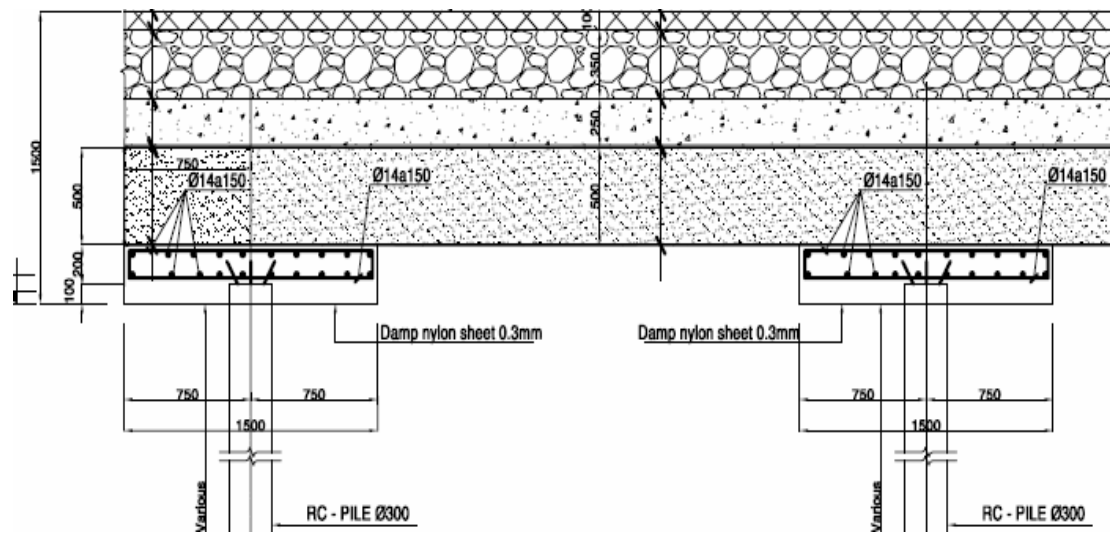

Fig. 13. Design of (IGW) used for Hung Loi Metro in Can Tho City

Deformation of the structure after completion of project in Fig. 14.
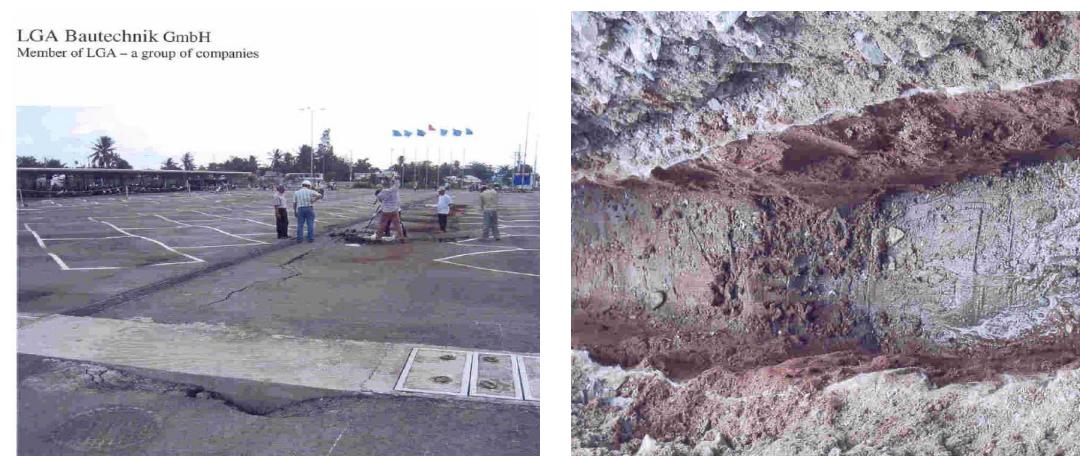

Fig. 14. Differential settlement of Hung Loi Metro project 


\section{The development of the new model}

Redesign the model using reinforced concrete piles with B.20, cross section area of $300 \times 300 \mathrm{~mm}$, spacing between piles varies from $1.0 \mathrm{~m}, 1.5 \mathrm{~m}$, $2.0 \mathrm{~m}, 2.5 \mathrm{~m}$, using Mac 40 geotextile to put on the top of each pile. Sand layer is $1 \mathrm{~m}$ high, reinforced concrete thickness of $150 \mathrm{~mm}$. Using Plaxis 3D Tunnel and Mohr-Coulomb to model with the following parameters.

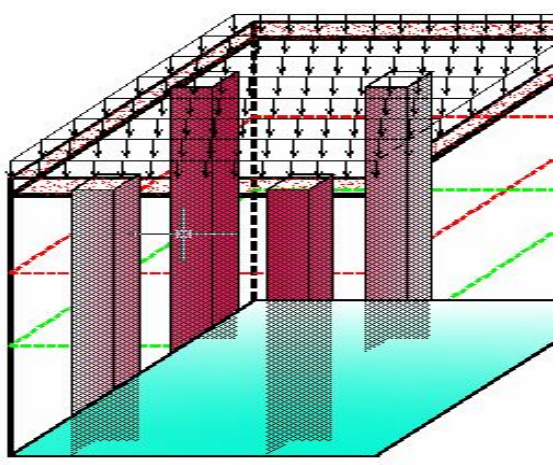

Fig. 15. The development of the new model to repair Hung Loi Metro in Can Tho city

Table 4

Properties of soil layers

\begin{tabular}{|l|c|c|c|c|c|c|}
\hline \multicolumn{1}{|c|}{ Properties } & Index & Layer 1 & Layer 2 & Layer 3 & $\begin{array}{c}\text { Sand } \\
\text { layer }\end{array}$ & \multirow{2}{*}{ Unit } \\
\cline { 3 - 6 } & Soft soil & stiff clay & $\begin{array}{c}\text { Sand } \\
\text { embank } \\
\text { ment }\end{array}$ & \\
\hline $\begin{array}{l}\text { Horizontal coefficient } \\
\text { ratio }\end{array}$ & $\mathrm{k}_{\mathrm{x}}$ & $0.214 * 10-6$ & $1.2 * 10-4$ & $2 * 10-2$ & $3 * 10-2$ & $\mathrm{~cm} / \mathrm{s}$ \\
\hline Vertical coefficient ratio & $\mathrm{k}_{\mathrm{y}}$ & $0.12 * 10-6$ & $0.6 * 10-4$ & $1 * 10-2$ & $1 * 10-2$ & $\mathrm{~cm} / \mathrm{s}$ \\
\hline $\begin{array}{l}\text { Modulus of elasticity of } \\
\text { the unstabilized soil } \\
\text { surrounding }\end{array}$ & $\mathrm{E}_{\mathrm{oed}}$ & 1252 & 14900 & 28860 & 30000 & $\mathrm{kN} / \mathrm{m}^{2}$ \\
\hline Poisson ratio & $v$ & 0.35 & 0.33 & 0.3 & 0.3 & - \\
\hline Cohesion & $\mathrm{C}$ & 8 & 71 & 1 & 1 & $\mathrm{kN} / \mathrm{m}^{2}$ \\
\hline Angle of friction of soil & $\varphi$ & $18^{0} 16$ & $26^{0} 58^{\prime}$ & $30^{\circ}$ & $30^{\circ}$ & $\mathrm{degree}$ \\
\hline
\end{tabular}

Table 5

Properties of reinforced concrete pile

\begin{tabular}{|l|c|c|c|}
\hline \multicolumn{1}{|c|}{ Properties } & \multicolumn{2}{c|}{ Index } & Unit \\
\hline $\begin{array}{l}\text { Modulus of elasticity } \\
\text { reinforced concrete }\end{array}$ & $E$ & $2.9^{*} 10^{7}$ & $\mathrm{kN} / \mathrm{m}^{2}$ \\
\hline Area of section & $A$ & $0.3^{*} 0.3$ & $\mathrm{~m} 2$ \\
\hline Poision ratio & $v$ & 0.15 & - \\
\hline Base thickness & $h$ & 0.15 & $\mathrm{~m}$ \\
\hline
\end{tabular}




\subsection{The analysis of model used Plaxis $3 d$ Tunnel software}

\subsubsection{Pile subsidence}

To create the spherical dome, there should not be any subsidence on the piples, the limit subsidence is $S<=10 \mathrm{~mm}$

\subsubsection{The effect of geotextile}

Geotextile with high expansion, there should not be any damange on geotextile under load.

\subsubsection{Sand layer}

Sand particles are big with $c^{\prime}=1 \mathrm{kN} / \mathrm{m} 2, \varphi^{\prime}=30$ degrees, the height of sand layer should be corresponding to the distance between piles.

\subsubsection{Reinforced concrete layer}

There needs to be reinforced concrete layer for the load distribution to avoid stress concentration on critical points.

\subsection{The analysis result of the model}

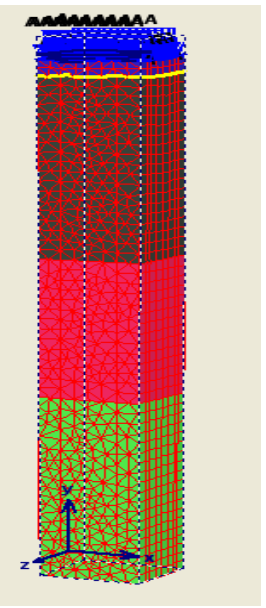

Fig. 16. Model in Plaxis

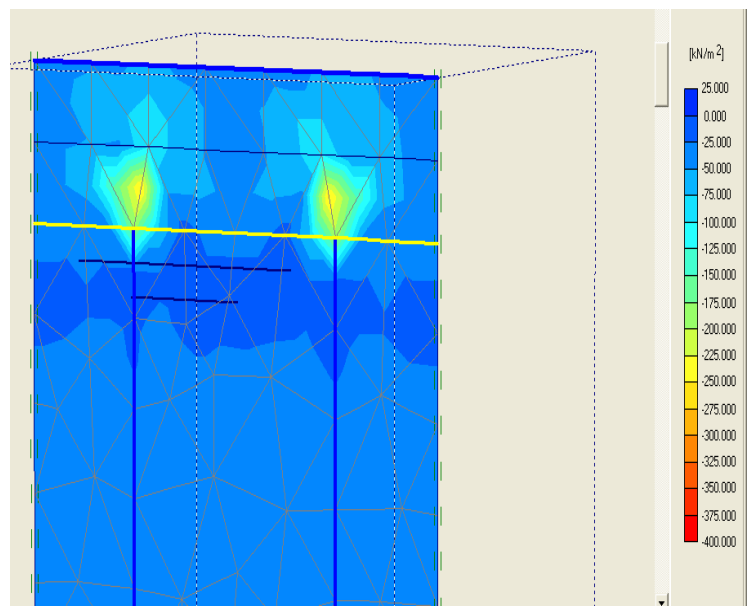

Fig. 17. The vertical stress on top of the top pile

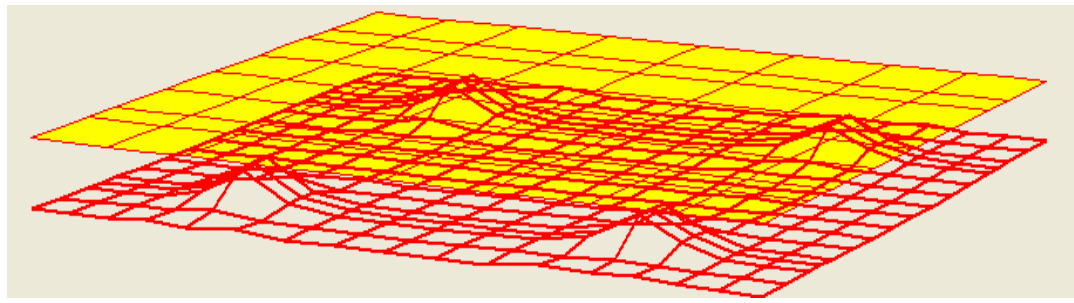

Fig. 18. The tensile force per meter geosynthetic

\subsubsection{Stress Distribution}

Below are the graphs of the relationship between stress distribution and the pile spacing. 
With the pile spacing $S=1 \mathrm{~m}$ and $S=1.5 \mathrm{~m}$, the vertical stress value at the top of the pile is maximum, in the higher up than the top of the pile, the vertical stress tends to decrease and distributed equally near the armoured concrete slab.

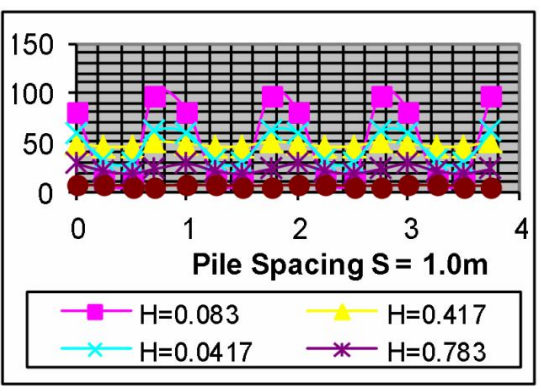

Fig. 19. The vertical stress on top of the top pile with $S=1.0 \mathrm{~m}$

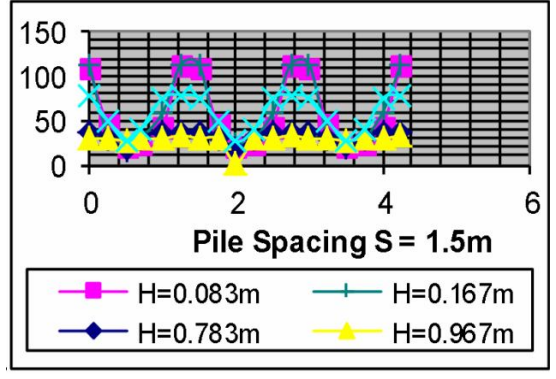

Fig. 20. The vertical stress on top of the top pile with $S=1.5 \mathrm{~m}$

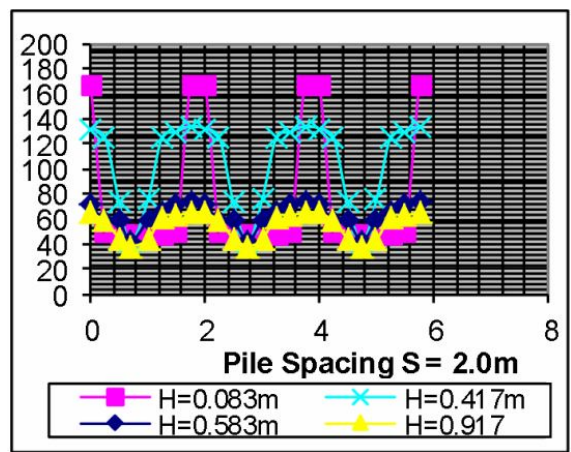

Fig. 21. The vertical stress on top of the top pile with $S=2.0 \mathrm{~m}$ top pile ratio $n=\sigma_{c} / \sigma_{s}$

- Spacing between piles and hight embankment $S=1 \mathrm{~m}, H=1 \mathrm{~m}$

When $S=1 \mathrm{~m}, H=1 \mathrm{~m}$. The stress concentration factor at the top of the pile is $n=6.8$, in the higher up than the pile head, the vertical stress tends to decrease and distributed equally near the armoured concrete slab. The stress concentration factor $n=1.12$.

- Spacing between piles and spacing between pile $S=1.5 \mathrm{~m}$, $H=1 \mathrm{~m}$.

When $S=1.5 \mathrm{~m}, H=1 \mathrm{~m}$. The stress concentration factor at the top of the pile is decreased $n=4.93$, in the higher up than the pile head, the 


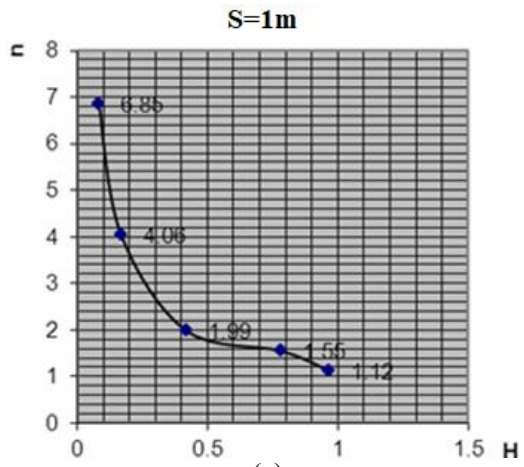

(a)

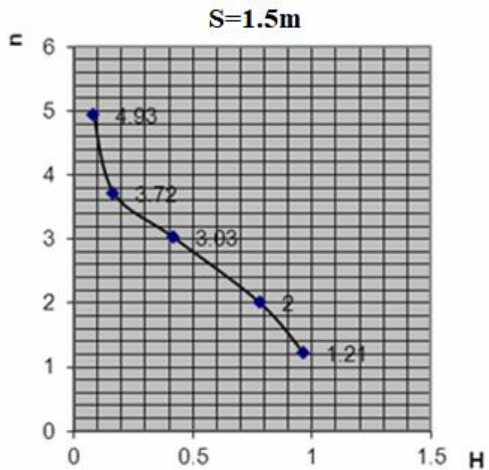

(b)

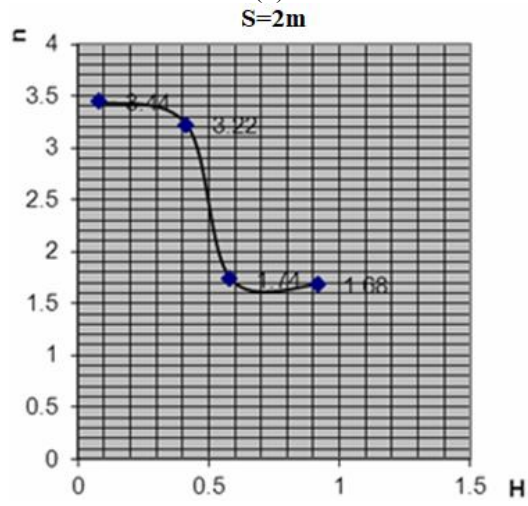

(c)

Fig. 23. Relation between the vertical stress on top of the top pile ratio and hight embankment with spacing between piles is $1 \mathrm{~m}$ (a), $1.5 \mathrm{~m}$ (b), $2.0 \mathrm{~m}$ (c) vertical stress tends to decrease and distributed equally near the armoured concrete slab. The stress concentration factor $n=1.12$.

- Spacing between piles and spacing between pile $S=2 \mathrm{~m}, H=1 \mathrm{~m}$.

When $S=2 \mathrm{~m}, H=1 \mathrm{~m}$. The stress concentration factor at the top of the pile is decreased $n=3.44$, in the higher up than the pile head, the vertical stress tends to decrease and not distributed equally near the armoured concrete slab. The stress concentration factor $n=1.68$.

\section{Conclusion and} recommendation

\subsection{Conclusion}

- The coefficient of stress concentration $n$ or the inverse $n^{*}$ will depend on the distance between piles. The further the distance is, the more $n$ decreases and the more $n^{*}$ increases.

- The height $h_{\text {dap }} \geq S$ will make the spherical dome become clearer. When $\quad h_{\text {dap }} \geq S / 2$ then $h g=S / 2$. When $h_{\text {dap }}<S / 2$ then arching height $h g=h_{\text {dap }}$.

- When the height cao $h_{\text {dap }}<S / 2$ the deformation is not uniform, and the other way around. When choosing the sand layer, we should choose $h_{\text {dap }}>S / 2$ and depend on the distance between the piles.

\subsection{Recommendation}

- Structure of the project is not reasonable. We should choose Structure of the project bearing capacity distribution.

- When applying the new model, notice that the distance between piles and the height should be carefully considered to improve and increase the efficiency of the arching.. 


\section{REFERENCES}

1. B. Le Hello, B. Chevalier, G. Combe, P. Villard, Coupling finite elements and discrete elements methods, application to reinforced embankment by piles and geosynthetics.

2. Chau Ngoc An, Foundation, Publishers National University Ho Chi Minh City, (2012).

3. Nguyen Minh Tam, The behavior of DMC column under hightway embankments by finite element analysis , (2006).

4. H.-G. Kempfert, Lateral spreading in basal reinforced embankments supported by pile-like elements , University Kassel, Germany March 2008.

5. Hans-Georg Kempfert Berhane Gebreselassie, Excavations and Foundations in Soft Soils, University Kassel, Germany.

6. H.-G. Kempfert \& M. Raithel \& A. Kirchner, Pile-supported embankments on soft ground for a high speed railway - Load Transfer, Distribution and Concentration by different construction methods

7. Kempfert, H. - G, Stadel, M. and Zaeske, D. Design of geosynthetic-reinforced bearing layers over piles. Bautechnik, Vol. 74, No. 12, December 1997

8. BS 8006 (1995): British Standard, code of practice of strengthened/ reinforced soils and other fills, chapter 9

9. Pham Quang Long, Existing problems of Vietnamese design standards for highway embankment on soft ground

10. Nguyen Minh Tam, The behavior of DCM (Deep ciment mixing) columns under highway embankments by finite element analysis, august 2006

11. Terzaghi, K. (1943), Theoretical Soil Mechanics, Jonh Wily anh Sons, New York

12. Hans-Georg Kempfert Berhane Gebreselassie, Excavations and Foundations in Soft Soils, University Kassel, Germany

13. H.-G. Kempfert \& M. Raithel \& A. Kirchner, Pile-supported embankments on soft ground for a high speed railway - Load Transfer, Distribution and Concentration by different construction methods

14. Hewlett, W. J., and Randolph, M.F. Analysis of piled embankments. Ground Engineering, Vol. 22, No. 3, April 1988.

Стаття надійшла 03.07.2019

Nguyen Anh Tuan, Nguyen Tuan Phuong

EVALUTION ON STRESS DISTRIBUTION, DEFORMATION RATE IN EMBANKMENT AND SOFT SOIL REINFORCED CONCRETE PILE COMBINED GEOTEXTILE BELOW THE EMBANKMENTS IN GEOLOGICAL CONDITIONS MEKONG DELTA

With the rapid growth of the economy and the trend of industrialization and mordenization of the country, the demand of developing buildings, factories and other infrastructures in Vietnam increases, especially in the Mekong Delta area. Because of the geological structure property of Mekong Delta is mainly soft soil, the foundation depth can vary from 30 to $40 \mathrm{~m}$. To meet the demand of infrastructure development, there some studies and researches done recently on this geological structure.

The evaluation and analysis on stress distribution, ground deformation and reinforced concrete and geotextile treatment on soft soil is extremely essential to find the new solution to improve the quality of foundation in Mekong Delta area. The main content of the paper is evalution stress distribution, deformation rate in embankment and soft soil reinforced concrete pile combined geotextile below the embankments in geological conditions in Mekong delta by finite element method to Geotechnique-designer have to notice the correlation of rational pile-distance and embankment-depth when design weak foundation.

Keywords: Geosynthetic reinforced pile, soft soil, pile embankment, foundation, FEM. 


\section{Нгуен Ань Туан, Нгуен Туан Фыонг}

\section{ОЦЕНКА РАСПРЕДЕЛЕНИЯ НАПРЯЖЕНИЙ, СКОРОСТИ ДЕФОРМАЦИИ НА НАСЫПИ И ГЕОТЕКСТИЛЕ КОМБИНИРОВАННОГО БЕТОНА ИЗ МЯГКОГО ГРУНТА В ГЕОЛОГИЧЕСКИХ УСЛОВИЯХ ДЕЛЬТЫ РЕКИ МЕКОНГ}

С быстрым ростом экономики и тенденцией к индустриализации и модернизации страны, спрос на строительство зданий, фабрик и других видов инфраструктур во Вьетнаме увеличивается, особенно в области дельты Меконга. Из-за особенностей геологической структуры в дельте реки Меконга преобладают мягкие грунты. Глубина заложения фундаментов сооружений может варьироваться от 30 до 40 метров. Чтобы удовлетворить потребность в развитии инфраструктуры, недавно были проведены некоторые исследования этой геологической структуры.

Были выполнены оценка и анализ распределения напряжений, деформации грунта, железобетонных конструкций и геоткани в мягком грунте. Такая оценка чрезвычайно важна для поиска новых подходов, направленных на улучшение характеристик фундаментов сооружений в районе дельты реки Меконг. Основным методом исследования является метод конечных элементов.

Ключевые слова: армированный геосинтетический материал, мягкий грунт, насыпной грунт, фундамент, метод конечных элементов.

\section{УДК 539.3}

Нгуєн Ань Туан, Нгуєн Туан Фионг. Оцінка розподілу напружень, швидкості деформації насипу при спорудженні комбінованих 3 геотканиною пальових фундаментів в геологічних умовах слабких грунтів дельти річки Меконг // Опір матеріалів і теорія споруд: наук.-тех. збірн. - К.: КНУБА, 2019. - Вип. 103. - С. 17-32.

Іл. 23. Библіогр. 14 назв.

\section{UDC 539.3}

Nguyen Anh Tuan, Nguyen Tuan Phuong. Evalution on stress distribution, deformation rate in embankment and soft soil reinforced concrete pile combined geotextile below the embankments in geological conditions Mekong delta// Strength of Materials and Theory of Structures: Scientific-and-technical collected articles. - K.: KNUBA, 2019. - Issue 103. - P. 17-32.

Fig. 23. Ref. 14.

Автор (вчена ступень, вчене звання, посада): PhD, Lecturer, Faculty of Transportation Engineering, Hochiminh City University of Transport, Nguyen Anh Tuan

Адреса: No. 2, D3 St., Ward 25, Binh Thanh Dist., Hochiminh City, Vietnam.

Тел.: (+84) 917.863.898.

Імейл: tuankct@hcmutrans.edu.vn

Автор (вчена ступень, вчене звання, посада): PhD, Lecturer, Faculty of Civil Engineering, Hochiminh City University of Technology, Nguyen Tuan Phuong

Адреса: No. 268, Ly Thuong Kiet St., Dist. 10, Hochiminh City, Vietnam.

Тел.: (+84) 919.070.096.

Імейл: tuanphuongvk@gmail.com 